\title{
Arms, Influence and the Treaty on the Prohibition of Nuclear Weapons
}

\section{Kjølv Egeland}

The 2017 Treaty on the Prohibition of Nuclear Weapons (TPNW) has correctly been described as a 'challenge to nuclear deterrence'. ${ }^{1}$ But what, precisely, is the nature of the challenge? Prohibiting the development, hosting and use of nuclear weapons, as well as any assistance, encouragement or inducement of prohibited acts, the TPNW was negotiated with a view to amplifying anti-nuclear norms and galvanising nuclear-disarmament processes. Delegitimising nuclear weapons, supporters believe, will help create the conditions for the abolition of nuclear weapons and enhance international security in the long term. ${ }^{2}$ For its most strident opponents, however, the TPNW constitutes little more than moralistic posturing or, worse, an enabler for clandestine nuclear-weapons programmes or withdrawals from the Non-Proliferation Treaty (NPT). ${ }^{3}$ Others have praised the intentions of those seeking to abolish nuclear weapons, but hypothesised that the TPNW could produce dangerous unintended effects, such as unbalanced stockpile reductions or the destabilisation of deterrence relations and US alliances in Europe and East Asia. ${ }^{4}$ Still others have expressed concern about the apparent polarisation of the nuclear-security debate, urging more intellectual engagement across the divide between 'righteous abolitionists' and 'dismissive realists'. ${ }^{5}$ 
This article constitutes an attempt to bridge this gulf. Its purpose is not to pass judgement on the morality of nuclear-deterrence practices or to debate whether the aspiration of nuclear abolition is desirable. Instead, it aims to unpack the concept of deterrence and investigate the ways in which adher-ence to the TPNW could affect nuclear-deterrence relationships. A number of observers have contended that the TPNW 'bans' nuclear deterrence. Against these commentators, I maintain that the treaty prohibits overt nuclear-deterrence practices and, if fully implemented, could greatly reduce the risk of nuclear confrontation, but will not in and of itself eliminate the conditions for nuclear deterrence. Nuclear rearmament would remain a threat - and hence a potential source of deterrence - even in a world without nuclear weapons. Moreover, pending the advent of such a world, non-nuclear-weapons states allied to nuclear-armed states, also known as nuclear 'umbrella states', could continue to benefit from extended nuclear deterrence even as parties to the TPNW. All else being equal, adherence to the TPNW by a nuclear-umbrella state would produce only an incremen-tal reduction of the salience of nuclear weapons in its security doctrine. Attaining and maintaining a world without nuclear weapons will most likely require a range of supporting politico-legal instruments and actions.

\section{Deterrence in theory and practice}

The English term 'deterrence' comes from the Latin word deterre, which means 'to frighten from or away'. ${ }^{6}$ In the words of the British theorist and civil servant Michael Quinlan, the practice of deterrence provides a means of 'helping to influence others against taking action that would be unwelcome to us, by putting clearly before them the prospect that the action will prompt a response that will leave them worse off than if they had not taken it'. ${ }^{7}$ In international relations, the concept of deterrence is most often used to describe the act of convincing, or seeking to convince, an adversary not to attack militarily. To 'convince', in this context, means, in the words of Patrick Morgan, 'to penetrate and manipulate the thought processes of the opposing leaders so that they draw the "proper" conclusion about the utility of attacking'. ${ }^{8}$ In practice, it is difficult to isolate the independent deterrent effect of a country's nuclear assets from its other military 
capabilities: conventional weapons, cultural factors and natural obstacles such as mountains or oceans may also function as deterrents. Conceptually, however, nuclear deterrence occurs when an actor is discouraged from taking a course of action that would be unwelcome to another through fear of nuclear reprisals by the aggrieved party. Extended nuclear deterrence occurs when an actor is discouraged from taking a course of action that would be unwelcome to another through fear of nuclear reprisals by a third party. For the renowned deterrence theorist Thomas Schelling, the difference between deterring aggression against the national homeland and deterring aggression against "everything "abroad" is the difference between threats that are inherently credible, even if unspoken, and the threats that have to be made credible'. ${ }^{9}$ Nevertheless, the underlying logic of deterrence

- refraining from undertaking an action out of fear of adverse consequences - remains the same irrespective of whether the adverse consequences are to be administered by a direct opponent or by a third party. Strategists commonly also differentiate between deterrence and compellence. While compellence involves the act of convincing an adversary to do something, deterrence involves the act of convincing an adversary not to do something. ${ }^{10}$

Four points about deterrence are worth stressing here. Firstly, the practice of deterrence must be carefully distinguished from the psychological phenomenon of deterrence. This distinction is often lost in the policy literature on nuclear deterrence and disarmament, including that on the TPNW. Secondly, successful deterrence does not necessarily require the deterrent threat to be wholly or even moderately credible. The potential impact of a nuclear strike is of such a magnitude that even a sliver of credibility could be enough to convince an opponent that the possibility of nuclear retalia-tion outweighed any potential benefit of aggression. Equally, even credible threats sometimes fail to deter. Thirdly, contrary to conventional wisdom, nuclear deterrence based on 'mutually assured destruction' is not obviously based on 'rational' premises in the socialscientific sense of the term. Lastly, the concept of deterrence is not a neutral analytical category, but interde-pendent with the social world its users seek to explain. There is constant slippage between the scholarly discussion of deterrence and the practice of deterrence by political actors. 
Deterrence as practice and phenomenon

Deterrence is often associated with nuclear strategy, but is in fact pervasive throughout the animal kingdom, including human societies. As Lawrence Freedman points out, manipulating the behaviour of others through threats is a natural phenomenon: 'The fittest often survive through persuading potential predators that they are too fast to be caught, that they will fight back if they are, and that even if they can be overwhelmed, they are inedible."11 For the pur-poses of this article, however, it is crucial to differentiate between the practice of deterrence on the one hand, and the phenomenon of deterrence on the other. While the former refers, as Schelling puts it, to the art and science of 'influenc-ing the choices that another party will make, and doing it by influencing his expectations of how we will behave', ${ }^{12}$ the latter refers to the fact, says Quinlan, that 'people customarily seek, whether consciously or not, to take into account the probable consequences of what they do. They refrain from actions whose bad consequences for them seem likely to outweigh the good ones. ${ }^{13}$

Drawing on social theory, the practice of nuclear deterrence may be con-ceived as an 'open-ended, spatially-temporally dispersed nexus of doings and sayings' related to the art and science of nuclear deterrence. ${ }^{14}$ This nexus of doings and sayings - development and deployment of nuclear forces, talk of 'fire and fury' and so on - is independent from the actual, psychological phenomenon of nuclear deterrence. As Richard Ned Lebow argues, threat-based strategies 'can provoke the very kind of behaviour they are implemented to prevent if they are perceived as offensive in intent':

Khrushchev made grossly exaggerated claims about Soviet strategic capability in the aftermath of the launching of Sputnik in 1957, and exploded gigantic nuclear devices in the early 1960s, to intimidate and restrain the US. The Eisenhower and Kennedy administrations played the same game; in 1961, Kennedy advertised publicly and privately the superiority of American strategic forces and his willingness to conduct a first strike under certain circumstances, left largely undefined. He hoped to deter Khrushchev from making another move against Berlin. Evidence from Soviet sources indicates that Kennedy's threats were a principal incentive for Khrushchev to send missiles to Cuba. ${ }^{15}$ 
The practice of deterrence, Lebow points out, can sometimes produce the opposite of its intended effect. Adversaries may be impervious to risk or simply fail to comprehend the message. But not only do practices of deter-rence sometimes not translate into the psychological phenomenon of deterrence on the receiving end, the phenomenon of deterrence can occur without any one actor having deliberately engaged in the practice of deter-rence. For example, criminal punishment motivated only by a desire for revenge could in many cases deter future crime. Equally, brutal sentencing practices aimed at deterrence could foment civil unrest and revolution. The occurrence of the phenomenon of deterrence, in other words, is not up to the one issuing the deterrent threat, but to those on the receiving end.

The credibility of deterrent threats

Actors seeking to deter others from taking a particular course of action typically endeavour to make their implicit or explicit deterrent threat as credible as possible. Deterrence theorists such as Schelling and Bernard Brodie devoted much of their intellectual capacity to the study of credibility. After all, if actor A does not believe that actor B will ever carry out its deter-rent threat, $A$ is unlikely to be deterred. It is important to note, however, that successful deterrence does not require convincing the opponent that punishment is inevitable (although threats of inevitable punishment could certainly strengthen the deterrent effect). ${ }^{16}$ For example, a state leader may judge the likelihood of being caught meddling in another state's elections to be extremely low, but still be deterred from authorising any meddling based on the calculus that any possibility of punishment outweighed the benefits of disrupting the other state's democratic process. From the per-spective of an attacker, aggression constitutes a risk. In this view, an attacker assesses the feasibility of aggression by combining the credibility of punish-ment with the severity of that punishment.

Nuclear threats typically score low on credibility and extraordinarily high on severity. These dimensions are of course intimately connected; the low credibility of a nuclear threat is in large measure a consequence of its severity. The implication is that nuclear threats lack credibility against any-thing short of serious violations of vital interests. However, on the higher 
end of the scale of provocations, nuclear threats may well be just about credible enough to deter. An actor may also be deterred from taking a particular course of action through fear of provoking a spiral of escalation that ultimately could lead to a nuclear confrontation. In his 1989 memoir, the former UK defence minister Denis Healey argued that 'it takes only five percent credibility of American retaliation to deter the Russians [from invading Western Europe] but ninety-five percent credibility to reassure the Europeans'. ${ }^{17}$

\section{The irrationality of nuclear retaliation}

The use by influential deterrence theorists of rational-choice theory and formal modelling has contributed to the widespread perception that mutually assured destruction (MAD) rests on rational premises. Scholarship on MAD has often been referred to as 'Rational Deterrence Theory', ${ }^{18}$ and one of the standard critiques of nuclear-deterrence strategies is that 'rogue states' and terrorist groups cannot be deterred because they are not rational. But MAD is derived neither from rational premises nor from game theory. In the words of Hedley Bull, 'It is not the case, as is sometimes argued, that these ideas are derivable from formal game theory or that in Schelling's case they have in fact been derived in this way: they represent an imaginative, conceptual exercise.'19 While Rational Deterrence Theory may be logical and analytically elegant, the basic assumptions on which it rests are not nec-essarily rational. In fact, several theorists have pointed out that launching a nuclear second strike in response to a large-scale nuclear assault is not, strictly speaking, rational. After all, the infliction of retaliatory nuclear vio-lence would not mitigate the damage caused by the initial strike, but add to the destabilisation it had caused to the earth's climate. As the authors of "Blunt Not the Heart, Enrage It": The Psychology of Revenge and Deterrence' put it:

Classic theories of deterrence emerged in the wake of the nuclear revolution and required that for deterrence to be stable, both actors had to commit to an otherwise seemingly irrational course of action: nuclear retaliation in response to a first strike. Such a commitment is awkward 
within a rationalist framework because, as many theorists have pointed out, a second-strike attack cannot undo or mitigate the apocalyptic damage delivered in a first strike. ${ }^{20}$

At the same time, however, the irrationality of nuclear retaliation does not imply that threats of nuclear retaliation are never credible: 'In short, despite arguments and assumptions that deterrence rests on assumed calculated rationality, the only truly credible aspect of deterrence lies in the authen-tic emotional power and psychological persuasion of the human drive for revenge in the face of violation or attack. ${ }^{21}$

\section{Deterrence and the double hermeneutic}

Scientific theories such as the laws of thermodynamics have no direct impact on, or engagement with, the subject matter they explain. Energy does not care or know about the first law. Many social-science theories, by contrast, including deterrence theories, are deeply intertwined in society. Anthony Giddens describes this phenomenon as the 'double hermeneutic'. For Giddens, 'the subjects of study in the social sciences and the humani-ties are concept-using beings, whose concepts of their actions enter in a constitutive manner into what those actions are'. ${ }^{22}$ Social-scientific con-cepts, then, do not just explain the world, they also shape it. For example, Jean Bodin and Niccolò Machiavelli did not simply describe an indepen-dently occurring series of social changes, 'They helped constitute the state forms that emerged from those changes. Modern states could not exist at all were not concepts such as "citizen", "sovereignty", and "government" itself, mastered by the individuals who administer them and those subject to their rule. ${ }^{23}$ Deterrence, in this view, is not a neutral analytical concept detached from the social world. The concept and theories of deterrence have direct impacts on the world through the scholarship of experts and the use and questioning of those theories by the actors whose behaviour the theories are supposed to explain. Benoît Pelopidas put this succinctly when he observed that the concept of deterrence does 'double work'. ${ }^{24}$ Deterrence theorists typically seek both to describe the world and, at the same time, to act on it: 
Saying that deterrence works is intended to make it work or at least to help it work better. It is meant to be a self-fulfilling prophecy. As a consequence, for these utterances to be able to work better, their authors have to deny their intention to produce an effect. They have to appear authoritative as descriptions and nothing more in order to have the intended effect. ${ }^{25}$

Nuclear weapons may well have fostered stability and restraint in many instances, but, as noted by the author Martin Amis, 'the trouble with [nuclear] deterrence is that it can't outlast the necessary time-span, which is roughly between now and the death of the sun'. ${ }^{26}$ Many longstanding nuclear-arms-control proposals, such as the de-alerting of nuclear forces, aim precisely at hedging against the prospect that an irrational outburst of emotions may be quickly translated into catastrophic nuclear violence. One of the central challenges to the long-term viability of nuclear deterrence is the danger of technological malfunction and inadvertent escalation. ${ }^{27}$

The fact that the effectiveness of nuclear deterrence relies, in part, on the degree to which political leaders accept the basic premises of deterrence theories has led many theorists to view efforts at devaluing and delegiti-mising nuclear weapons with hostility. Criticising deterrence practices, says Pelopidas, is 'portrayed as both perverse and jeopardizing', as weakening the deterrent effect of such practices and thereby undermining international stability. ${ }^{28}$ In the late 1950s, for example, Henry Kissinger argued vigorously against the adoption of a ban on nuclear testing, maintaining that such a step would undercut deterrence and cause a dangerous rift in NATO. ${ }^{29}$ Just like many contemporary critics of the TPNW, Kissinger saw the West's alleged insistence on 'moral perfection' as a dangerous weakness. ${ }^{30}$ US allies' squeamishness about nuclear war had to be dispelled:

One of the chief tasks of United States policy in NATO ... is to overcome the trauma which attaches to the use of nuclear weapons and to decentralize the possession of nuclear weapons as rapidly as possible. Nothing would so much dispel the mystery of nuclear weapons as their possession by the Continental powers. Nothing would do more to help restore a measure of consistency to allied military planning. ${ }^{31}$ 
In hindsight, the 'trauma which attaches to the use of nuclear weapons' appears to have helped curb proliferation and avoid war with nuclear weapons. ${ }^{32}$ Taking the opposite view to the one propounded by Kissinger in the 1950s, the 189 parties to the NPT agreed in 2010 on the need 'for further progress in diminishing the role of nuclear weapons in security policies'. ${ }^{33}$ The logical end point of this process - the abolition of nuclear weapons - remains a stated goal of virtually all states. Of course, the goal of creating a nuclear-free world has often been criticised. Schelling and others have argued that a nuclear-free world would provide the most dangerous of all possible nuclear balances, incentivising rapid rearmament and pre-emptive nuclear strikes. ${ }^{34}$ While a full discussion of this claim falls outside the scope of this article, suffice it to point out that several commentators have disputed Schelling's hypothesis. While it is true that nuclear weapons cannot be disinvented, fissile material can be controlled, warheads can be verifiably eliminated and norms can be cultivated. ${ }^{35}$

\section{The impact of the TPNW on nuclear-deterrence relations}

Adopted in July 2017, the TPNW prohibits its parties from possessing, hosting, using or threatening to use nuclear weapons, as well as from assist-ing, encouraging or inducing prohibited activities. ${ }^{36} \mathrm{~A}$ perfunctory reading of these prohibitions would suggest that the TPNW rules out any reliance on nuclear deterrence. Indeed, both proponents and opponents of the TPNW have contended that the new treaty 'bans deterrence'. Hirofumi Tosaki avers that the TPNW 'legally prohibits reliance on nuclear deterrence'. ${ }^{37}$ Paul Meyer and Tom Sauer have likewise argued in this journal that nuclear deterrence will become 'illegal':

The ban treaty will forbid the development, production, testing, acquisition, stockpiling, transfer, possession and stationing - as well as the use and threat of use - of nuclear weapons. Consequently, the decades-old doctrine of nuclear deterrence will become illegal for the signatory states, and in the eyes of the hundreds of millions of citizens around the world who support the treaty. ${ }^{38}$ 
Commentators have also maintained that the TPNW prohibits reliance on extended nuclear deterrence. For example, Ramesh Thakur suggests that the TPNW 'could be interpreted to read that it prohibits extended nuclear deterrence' ${ }^{39}$ Matthew Harries argues that the treaty 'implicitly prohibits a state party from receiving any kind of nuclear deterrence guarantee' ${ }^{40}$ The authors of a Harvard Law School study assert that the treaty's prohibitions 'make it unlawful for a state party to benefit from the protection of a nuclear umbrella arrangement ${ }^{\prime}{ }^{41}$ I maintain that these assertions are inaccurate. As long as nuclear rearmament and use remain possible, the conditions for nuclear deterrence will exist. The effect of the TPNW on deterrence relations will in large part depend on how states frame and implement their own, and their allies', obligations under the treaty.

\section{'Threatening to use' nuclear weapons}

The practice of nuclear deterrence is often conceptualised as a strategy based on the implicit or explicit 'threat' to use nuclear weapons. During the TPNW negotiations, certain participants argued strongly in favour of including in the treaty an explicit prohibition against threatening to use nuclear arms. The Japanese non-governmental organisation Peace Boat - one of the organisations represented in the Steering Group of the International Campaign to Abolish Nuclear Weapons (ICAN) - submitted a working paper to the negotiating conference asserting that the 'threat of use of nuclear weapons is at the core of nuclear deterrence policy'. The concept of nuclear deterrence 'has provided the basis of justification' for the retention of nuclear weapons, Peace Boat observed, concluding that it was therefore important that the TPNW 'clearly prohibit the threat of use of nuclear weapons so that the policy of nuclear deterrence is provided unlawful' ${ }^{42}$ Accordingly, Article 1 of the TPNW enjoins its parties never, under any circumstances, to 'use or threaten to use' nuclear weapons. But does the prohibition against threatening to use nuclear weapons legally foreclose nuclear deterrence?

The legal literature on the concept of threats and their relationship to nuclear deterrence is inconclusive. ${ }^{43}$ There is no consensus among legal scholars on what constitutes a 'threat' in general, the specific conditions under which threatening to use nuclear force is lawful or unlawful, or the 
legal status of nuclear-deterrence practices such as MAD or the extension of nuclear security guarantees to third parties. ${ }^{44}$ It seems highly doubtful, however, that the possession of nuclear weapons could be said ipso facto to constitute a threat to use them in the legal sense. In his recently published legal commentary on the TPNW, Stuart Casey-Maslen argues that the pro-hibition against threatening to use nuclear weapons enshrined by Article 1 of the TPNW does not encompass either the mere possession of nuclear weapons or membership in alliances that include nuclear-armed states. ${ }^{45}$ The TPNW's prohibition against threatening to use nuclear weapons, then, does not rule out either the practice of, or the passive reliance on, nuclear deterrence. Israel, for example, has long been seen to practise nuclear deter-rence without ever having acknowledged its possession of nuclear arms. It would be difficult to argue that Israel has 'threatened' to use nuclear weapons in accordance with the accepted usage of that term.

\section{'Possessing' and 'using' nuclear weapons}

The effectiveness of the TPNW's claimed prohibition on nuclear deterrence does not rest solely on the prohibition against 'threatening to use' nuclear weapons. The TPNW also prohibits the hosting, possession and stockpiling of nuclear arms. However, even the full catalogue of prohibitions contained in the TPNW arguably does not preclude either the practice or the phenom-enon of nuclear deterrence. In fact, even in a nuclear-free world, each state would know that other states, in particular those with large civilian nuclear programmes, could manufacture nuclear weapons within a relatively short period of time. Parties to the TPNW with civilian nuclear technology and materials could thus engage in a form of 'weaponless' or 'virtual' nuclear deterrence. ${ }^{46}$ Other states could conceivably be deterred from taking particu-lar courses of action through fear of escalation and rearmament. Weaponless nuclear deterrence would operate at 'one remove' from the possession of nuclear weapons, ${ }^{47}$ possibly lessening the risk of accidents or inadvertent nuclear escalation, but nuclear deterrence would remain a feature in strategic affairs. That said, the TPNW would deem any acquisition (or reacquisition) and use of nuclear weapons illegal under international law, meaning that any practice of weaponless nuclear deterrence would rest on the possibility of 
future violations of the prohibitions against development, production, possession and use. Yet, while a legal prohibition and verification arrangements could help stigmatise nuclear weapons and constrain access to nuclear material, the existence of a legal regime would not in and of itself guarantee that nuclear arms could not nevertheless be acquired and used.

The abolition of current nuclear arsenals would not eliminate the risk of future nuclear rearmament and war. In the 1950s, several renowned authors therefore argued that the risk of nuclear war could only be satisfactorily managed through the institution of a world government that would monopolise the use of force, eliminate all nuclear weapons, and control nuclear materials and technology. ${ }^{48}$ In such a world, the conditions for nuclear deterrence would be constrained to an absolute minimum, and would for all practical purposes be an insignificant feature of world politics. Yet in theory, nuclear deterrence could still exist. For example, sub-state groupings could position themselves tactically in relation to the means of force or strategic sectors of the economy, deterring others from taking particular courses of action. The TPNW contains no provisions rendering such actions unlawful, and it is difficult to imagine how any legal document could comprehensively prohibit subtle attempts at influencing behaviour through the manipulation of nuclear fear - let alone nuclear fear itself. The conspicuousness of nuclear deterrence in world politics, in this view, is a matter of degree. The security doctrines of each of the world's states could be conceived as falling on a spectrum between aggressive nuclear grandstanding at one end, and a total rejection of any use of nuclear weapons at the other, with the de-alerting of nuclear forces, adoption of no-first-use policies, explicit reliance on extended nuclear deterrence and general alignment with nuclear-armed states constituting intermediary positions. All else being equal, each of these steps away from aggressive nuclear grandstanding would reduce the salience of nuclear weapons and deterrence in world affairs, likely strengthening the stigma associated with nuclear weapons.

\section{Extended nuclear deterrence and 'encouragement' of prohibited activities}

A number of observers have maintained that the TPNW renders extended nuclear deterrence unlawful. The textual justification for this claim is the 
prohibitions in Article 1(1) against providing or seeking 'assistance', 'encouragement' or 'inducement' to carry out prohibited activities. According to a commentary on the Chemical Weapons Convention, 'encouragement' means contributing to another actor's 'resolve' to commit a prohibited activity. ${ }^{49}$ The current practices of many so-called umbrella states would appear to fall foul of this standard. For example, NATO's 2010 Strategic Concept establishes that the allies will 'maintain an appropriate mix of nuclear and conventional forces' ${ }^{50}$ Endorsement of this statement could reasonably be read as a contri-bution to the 'resolve' of France, the United Kingdom and the United States to retain nuclear weapons. The UK government has consistently justified the construction of a new class of ballistic-missile submarines with reference to NATO documents and the demands for nuclear reassurance by allies, ${ }^{51}$ and successive US administrations have framed spending on nuclear-weapon systems as necessary to fulfil 'extended deterrence commitments' enshrined in Alliance documents. Ostensibly, these commitments oblige the United States to 'retain numbers or types of nuclear capabilities that it might not deem necessary if it were concerned only with its own defense'. ${ }^{2}$

Several observers, including the foreign minister of Norway, have maintained that ratification of the TPNW would not be legally incompatible with NATO membership. ${ }^{53}$ However, to comply with its international obligations, any party to the treaty would have to distance itself from statements or alliance documents endorsing the potential use of nuclear weapons. In theory, an umbrella state could accomplish this by issuing a declaration disavow-ing any possession or use of nuclear weapons appended to its instrument of ratification of the treaty. As argued by Casey-Maslen, ratification of the legally binding TPNW would then, as a matter of international law, 'over-ride' previous support for political documents such as NATO's Strategic Concept. ${ }^{54}$ That said, the legal compatibility of the treaty with membership in NATO and other alliances does not imply that adherence to the TPNW would be compatible with a signatory's actual good standing in NATO or other alliances. While collective-defence treaties typically do not contain provisions to expel existing parties, individual allies could suspend techni-cal cooperation, withhold data and intelligence, cancel joint exercises or sow doubt about their willingness to come to the TPNW adherent's aid. Such 
actions on the part of a signatory's allies would arguably have a much more profound effect on deterrence relations than would the act of acceding to the treaty.

Assuming, for the sake of argument, that it would be possible for an umbrella state to join the TPNW without being ostracised from its alliance, such adherence would not ipso facto prohibit it from 'benefiting' from extended nuclear deterrence. After all, accession to the TPNW by a nuclearumbrella state would not preclude that state's nuclear-armed allies from using nuclear armaments against a third party. The same applies to other non-universally banned weapons such as landmines, cluster munitions and chemical weapons. For example, Denmark's adherence to the Convention on Cluster Munitions would not legally prevent the United States from using cluster munitions in a conflict against a common enemy -including if the United States' involvement in the conflict had emanated from a Danish invocation of NATO's collective-defence clause. Denmark would of course be prohibited from requesting or assisting US use of cluster munitions, but could not be held legally responsible for the discretional actions of the US government. Equally, accession to the TPNW by Denmark would prohibit Copenhagen from assisting, encouraging or inducing the United States to use nuclear weapons - for example by hosting US tactical nuclear munitions on Danish territory - but would not prevent the United States from using nuclear weapons against a common enemy. It should also be pointed out that, in the scenario described above, Denmark's status as a de facto nuclear-weapon-free zone under the TPNW would survive only as long as Denmark or the major powers considered it in their interest to respect that status. ${ }^{55}$ Denmark's potential adversaries would of course be aware of this fact. As an illustration of this dynamic, Germany's adherence to the NPT has hardly convinced Russia that the US nuclear warheads stationed on German territory could not be (illegally) transferred to and used by German dual-key aircraft in the event of escalation.

A hypothetical Danish ratification of the TPNW, in other words, would not provide Swedish, Chinese or Russian leaders with a guarantee that aggression against Denmark (and thus NATO) could not escalate into a wider confrontation with Copenhagen's nuclear-armed allies. Were the 
United States, the United Kingdom or France to find themselves in a state of war with Russia, Denmark's views on the legality of strategic nuclear strikes against Moscow would be beside the point. As a 1995 US strategy document put it, 'nuclear weapons always cast a shadow over any crisis or conflict in which the US is engaged'. ${ }^{56}$ This argument holds even for states without a formal security guarantee. As Schelling argued in Arms and Influence, the credibility of extended deterrent threats does not rely on formal guarantees. The credibility, such as it was, of the United States' commitment to defend West Germany and Greece during the Cold War relied not primarily on the North Atlantic Treaty, but on the fact that the United States could not 'afford to let the Soviets overrun West Germany or Greece, irrespective of [US] treaty commitments to Germany or to the rest of Western Europe'. Indeed, the US may well have recognised 'an implicit obligation to support Yugoslavia, perhaps Finland, in a military crisis'. ${ }^{57}$ The import of Schelling's argument is that the phenomenon of deterrence, nuclear or conventional, does not rely on formal security guarantees or declarations, but on the enemy's belief that aggression could lead to allied involvement and escalation. Accession to the TPNW by an umbrella state would not eliminate this risk.

The TPNW and the credibility of extended nuclear deterrence

Accession to the TPNW by an umbrella state would not provide its adversaries with a guarantee that aggression against that state could not ultimately escalate into a nuclear war. Accordingly, the conditions for the psychological phenomenon of extended nuclear deterrence would remain. Moreover, alignment with a nuclear-armed state could be interpreted as a nucleardeterrence practice not prohibited by the TPNW. Under the definition provided above, alignment with a nuclear-armed state would constitute a deterrence practice if it was conceived as such by the umbrella state. From the point of view of an adversary, however, this would be a distinction without a difference.

While an umbrella state's accession to the TPNW would not necessarily eliminate the conditions for nuclear deterrence, it could reduce the credibility of nuclear deterrence in at least two ways. Firstly, as suggested above, an umbrella state's adherence to the TPNW could undercut the viability 
of certain nuclear-response options, such as the deployment of tactical nuclear weapons to the territory of the umbrella state. The overall strategic balance, however, would arguably remain largely unchanged. Admittedly, the incumbent US government has adopted the position that credible deterrence demands that the United States and NATO match Russia's and other potential adversaries' capabilities on every potential step of the escalation ladder, from hybrid actions via conventional operations to 'low-yield' tactical nuclear strikes and ultimately strategic nuclear war. This view has been challenged by a large section of the expert community. ${ }^{58}$ For example, it could be argued that having 'high-yield' strategic weapons as one's only response option could deter adversaries from conventional aggression or 'low-yield' tactical nuclear strikes due to the potential of rapid escalation to strategic nuclear war. ${ }^{59}$ As alluded to above, such debates are often particularly acrimonious because they operate on the level of the double hermeneutic of nuclear deterrence; Washington's suggestion that it might be self-deterred from responding to a 'low-yield' nuclear strike with a 'high-yield' response could potentially influence the choices of Washington's adversaries.

Secondly and more importantly, an umbrella state's accession to the TPNW could undermine the credibility of nuclear deterrence by adding to the stigma associated with the use of nuclear weapons. Already in the 1950s, policymakers in the United States and the United Kingdom were cognisant that anti-nuclear norms could increase the reputational costs of using nuclear weapons, and thus decrease the credibility of nuclear use. ${ }^{60}$ Operating again on the level of the double hermeneutic, the implicit argument is that the deterrent value of nuclear weapons could diminish if the use of such weapons came to be seen as socially unacceptable. For many supporters of the TPNW, however, the fact that the treaty could strengthen anti-nuclear norms and over time undermine the legitimacy and credibility of nuclear deterrence is precisely the point. As they see it, delegitimising and stigmatising nuclear weapons could reduce the risk of nuclear use and remove one of the key obstacles to nuclear disarmament, namely the 'prestige value' of nuclear weapons.

Opponents of the TPNW have argued that any normative impact of the ban is likely to be asymmetric - that the treaty could foster unbalanced dis- 
armament and instability. The NATO official Michael Rühle, for example, maintains that the TPNW 'will only affect Western democracies' because the 'delegitimisation of nuclear weapons can only work in places with a vibrant civil society'. ${ }^{61}$ This statement is not obviously correct - authoritarian states and non-Western democracies also appear to have been affected by nuclear norms ${ }^{62}$ - but even if we assume that the TPNW will only have an impact on Western democracies, it is not clear that asymmetric pressure will necessarily yield asymmetric outcomes. On the contrary, increased anti-nuclear pressure in and on France, the United Kingdom and the United States could just as likely translate into an increased willingness in those countries to engage the other nuclear-armed states in meaningful negotiations.

In the late 1950s and early 1960s, popular mobilisation against atmospheric nuclear testing in the Western and non-aligned worlds led to the negotiation by

the Soviet Union, the United Kingdom and the United States of the 1963 Partial Nuclear-Test-Ban Treaty - not to unilateral measures by the Western powers. ${ }^{63}$

Most, if not all, of the world's states have nominally agreed to enact nuclear disarmament. Supporters of the dominant 'step-by-step' approach to disarmament often point to the large stockpile reductions undertaken since the mid-1980s as proof that the world is on course to achieve the elimination of nuclear weapons. Yet the question remains whether such reductions (quantitative alterations of the status quo) can be used as evidence that the international community is truly on a path to abolition (a fundamental, qualitative transformation of the post-war international structure). While the arms-control approach may have made the world safer, it has arguably never challenged the norms and power structures that sustain nuclear-weapons programmes. ${ }^{64}$ And while the established major powers have downsized their arsenals, they continue to value their nuclear weapons, retaining stockpiles more than large enough to cause a nuclear winter. ${ }^{65}$ The 'doomsday clock' of the Bulletin of the Atomic Scientists has never been closer to midnight. Furthermore, notwithstanding 
important cases of 'de-proliferation' by Belarus, Kazakhstan, South Africa and Ukraine, the number of nuclear-armed states has grown since the end of the Cold War. It is thus far from clear that the international community is on a path to nuclear abolition. Many observers have maintained that this is likely to remain the case for as long as nuclear weapons are framed as legitimate instruments of security. From this perspective, delegitimising nuclear weapons would appear to constitute a necessary condition for the achievement of long-term solutions to the problem caused by the nuclear revolution. ${ }^{66}$

The TPNW constitutes a serious challenge to the legitimacy of nuclear-deterrence practices, but does not 'ban' nuclear deterrence. The treaty prohibits overt nuclear-deterrence practices such as threatening to use nuclear weapons, hosting nuclear weapons, possessing and deploy-ing nuclear weapons, and encouraging allies to engage in such activities, but it does not comprehensively foreclose either the phenomenon or the practice of nuclear deterrence. For example, the TPNW does not prohibit civilian nuclear programmes and thus allows for the practice of 'virtual' or 'weaponless' nuclear deterrence. The abolition of nuclear weapons would make nuclear deterrence less salient, but would not eliminate it as a factor in strategic affairs. Furthermore, the TPNW does not prohibit its parties from engaging in military alliances with nuclear-armed states so long as they refrain from any assistance, encouragement or inducement of prohib-ited activities. Ceteris paribus, such states could still 'benefit' from extended nuclear deterrence - whether they wished to or not. The fact that the TPNW does not actually outlaw nuclear deterrence is not an outcome of poor draft-ing on the part of the TPNW negotiators, but a consequence of the elusive nature of nuclear deterrence. A comprehensive prohibition on nuclear deter-rence would necessitate a comprehensive prohibition on nuclear fear. This, however, is unlikely to be feasible - or desirable.

The TPNW has often been framed as a competitor to the step-by-step approach to nuclear disarmament favoured by the nuclear-armed states and 
most of their allies. According to this approach, nuclear disarmament should be accomplished through the completion of a series of mutually reinforcing, incremental steps. On closer inspection, however, adherence to the TPNW by non-nuclear-weapons states and umbrella states would appear to be not only compatible with, but even complementary to, this approach. Framing nuclear weapons as fundamentally unacceptable instruments of warfare, the TPNW could help build a normative environment more conducive to nuclear disarmament. While adherence to the treaty by nuclear-umbrella states would not comprehensively eliminate extended nuclear deterrence, it would constitute a meaningful step on a path to reducing the salience of nuclear weapons in world affairs. Creating a stronger norm against nuclear weapons will not alone be sufficient to create a world without such weapons, but it may well be necessary.

\section{Notes}

1 Edward Ifft, 'A Challenge to Nuclear Deterrence', Arms Control Today, March 2017, https://www. armscontrol.org/act/2017-03/features/ challenge-nucleardeterrence.

2 See, for example, Beatrice Finn,

'The Logic of Banning Nuclear Weapons', Survival, vol. 59, no. 1, February-March 2017, pp. 43-50; and Nick Ritchie, 'The Real "Problem" with a Ban Treaty? It Challenges the Status Quo', Carnegie Endowment for International Peace, 3 April 2017, http:// carnegieendowment.org/2017/04/03/realproblem-with-ban-treaty-it-challengesstatus-quo-pub-68510.

3 See, for example, Michael Rühle, 'The Nuclear Weapons Ban Treaty: Reasons for Scepticism', NATO Review, 19 May 2017, https:// www.nato.int/docu/review/2017/alsoin-2017/nuclear-weapons-ban- treaty-scepticism-abolition/en/index. htm; and Heather Williams, 'Does the Fight over Nuclear Weapons Ban Threaten Global Stability?', Bulletin of the Atomic Scientists, 9 February 2017, http:// thebulletin.org/does-fight-over-nuclearweapons-ban-threaten-globalstability 10500.

4 See, for example, Matthew Harries, 'The Real Problem with a Nuclear Ban Treaty', Carnegie Endowment for International Peace, 15 March 2017, https:// carnegieendowment. org/2017/03/15/real-problem-with-nuclearban-treaty-pub-68286; and Scott Sagan and Benjamin A. Valentino, 'The Nuclear Weapons Ban Treaty: Opportunities Lost', Bulletin of the Atomic Scientists, 16 July 2017, https:// thebulletin.org/2017/07/the-nuclearweapons-ban-treaty-opportunities-

5 lost/.

See, for example, Lars-Erik Lundin, 
'Inquiry into the Consequences of a Swedish Accession to the Treaty on the Prohibition of Nuclear Weapons', Swedish Ministry of Foreign Affairs, January 2019, p. 175; and Jenny Nielsen, A Summer of Discontent: The Consolidation of Nuclear Disarmament and Deterrence Divides', European Leadership Network, 15 August 2016, https://www. europeanleadershipnetwork.org/ commentary/a-summer-of-discontent-theconsolidation-of-nuclear-disarmament-anddeterrence-divides/. The (somewhat leading) distinction between 'righteous abolitionists' and 'dismissive realists' originates in Michael Quinlan, 'Abolishing Nuclear Armouries', Survival, vol. 49, no. 4, Winter 2007-08, p. 8.

Lawrence Freedman, Nuclear Deterrence (London: Penguin, 2018), p. 1. 7 Michael Quinlan, Thinking About

Nuclear Weapons: Principles, Problems, Prospects (Oxford: Oxford University Press, 2009), p. 20.

8 Patrick M. Morgan, 'Saving Face for the Sake of Deterrence', in Robert Jervis et al. (eds), Psychology and Deterrence (Baltimore, MD: Johns Hopkins University Press, 1985), p. 125.

9 Thomas C. Schelling, Arms and Influence (New Haven, CT: Yale University Press, 1966), p. 36.

10 Ibid., pp. 69-71.

11 Lawrence Freedman, Deterrence

(Cambridge: Polity, 2004), p. 6. 12 Thomas C. Schelling, Strategy of

Conflict (Cambridge, MA: Harvard University Press, 1980 [1960]), p. 13. 13 Quinlan, Thinking About Nuclear

Weapons, p. 20.
14 Theodore R. Schatzki, 'A Primer on Practices', in J. Higgs et al. (eds), Practice-Based Education (Rotterdam: Sense Publishers, 2012), p. 14.

15 Richard Ned Lebow, 'Deterrence: Then and Now', Journal of Strategic Studies, vol. 28, no. 5, 2005, pp. 766-7.

16 Schelling, Arms and Influence, p. 35. 17

Cited in Matthew Fuhrmann, 'On

Extended Nuclear Deterrence', Diplomacy \& Statecraft, vol. 29, no. 1 , 2018, p. 65.

18 See, for example, Christopher $\mathrm{H}$. Achen and Duncan Snidal, 'Rational Deterrence Theory and Comparative Case Studies', World Politics, vol. 41, no. 2, 1989, pp. 143-69.

19 Hedley Bull, 'The Theory of International Politics 1919-1969', in Brian Porter (ed.), The Aberystwyth Papers: International Politics, 19191969 (Oxford: Oxford University Press, 1972), reproduced in Andrew Linklater (ed.), Critical Concepts in Political Science (London: Routledge, 2000), p. 66.

20 Rose McDermott, Anthony C. Lopez and Peter K. Hatemi, "'Blunt Not the Heart, Enrage It": The Psychology of Revenge and Deterrence', Texas National Security Review, vol. 1, no. 1, 2017, p. 70.

21 Ibid., p. 73.

22 Anthony Giddens, Social Theory and Modern Sociology (Cambridge: Polity Press, 1987), pp. 18-19.

23 Ibid., p. 20.

24 Benoît Pelopidas, 'Nuclear Weapons

Scholarship as a Case of Self-Censorship in Security Studies', Journal of Global Security Studies, vol. 1, no. 4, 2016, p. 329.

25 Benoît Pelopidas, 'Re-imagining 
Global Nuclear Ordering Beyond

Proliferation and Deterrence', paper prepared for POSSE, 2015, p. 8.

Martin Amis, Einstein's Monsters (London: Vintage, 1999), p. 17.

27 See Patricia Lewis et al., 'Too Close

for Comfort: Cases of Near Nuclear Use and Options for Policy', Chatham House, 2014, p. 9.

28 Pelopidas, 'Re-imagining Global Nuclear Ordering Beyond Proliferation and Deterrence', p. 14. 29 Henry A.

Kissinger, 'Nuclear Testing and the Problem of Peace', Foreign Affairs, vol. 37, no. 1, 1958, pp. 1-18.

30 Henry A. Kissinger, 'Missiles and the Western Alliance', Foreign Affairs, vol. 36, no. 3, 1958, p. 400.

31 Henry A. Kissinger, Nuclear Weapons and Foreign Policy (New York: Harper \& Brothers, 1957), p. 311.

32 See Nina Tannenwald, The Nuclear Taboo: The United States and the NonUse of Nuclear Weapons Since 1945 (Cambridge: Cambridge University Press, 2007).

33 Review Conference of the Parties to the Treaty on the Non-Proliferation of Nuclear Weapons, Final Document, Doc. NPT/CONF.2010/50 (Vol. I), 2010, p. 13.

34 Thomas C. Schelling, 'The Role of Deterrence in Total Disarmament', Foreign Affairs, vol. 40, no. 3, 1962. 35 See Harald Müller, 'Icons off the

Mark: Waltz and Schelling on a Perpetual Brave Nuclear World', Nonproliferation Review, vol. 20, no. 3, 2013, pp. 545-65.

36 'Treaty on the Prohibition of Nuclear Weapons', 7 July 2017, Article 1.

37 Hirofumi Tosaki, 'Japan's Nuclear

Disarmament Diplomacy Following the Adoption of the Treaty on the Prohibition of Nuclear Weapons (TPNW)', AJISS-Commentary, 20 October 2017, http://www2.jiia.or.jp/ en_commentary/201710/20-1.html.

38 Paul Meyer and Tom Sauer, 'The Nuclear Ban Treaty: A Sign of Global Impatience', Survival, vol. 60, no. 2, April-May 2018, p. 62.

39 Ramesh Thakur, 'Nuclear Turbulence in the Age of Trump', Diplomacy \&

Statecraft, vol. 29 , no. 1,2018 , p. 117.40

Matthew Harries, 'US Extended

Nuclear Deterrence Arrangements', in Shatabhisha Shetty and Denitsa Raynova (eds), Breakthrough or Breakpoint? Global Perspectives on the Nuclear Ban Treaty (London: European Leadership Network, 2017), p. 51.

41 International Human Rights Clinic, 'Nuclear Umbrella Arrangements and the Treaty on the Prohibition of Nuclear Weapons', Harvard Law School, 2018, p. 5.

42 Peace Boat, 'Developing a Robust Nuclear Weapons Ban Treaty', United Nations Conference to Negotiate a Legally Binding Instrument to Prohibit Nuclear Weapons, Leading Towards Their Total Elimination, UN doc. A/ CONF/229/2017/NGO/WP.19, 17 April 2017 , p. 3.

43 See, for example, International Court of Justice, 'Legality of the Threat or Use of Nuclear Weapons', Advisory Opinion, 1996; Yoram Dinstein,

'The Threat of Force in International Law', American Journal of International Law, vol. 102, no. 4, 2008, p. 919; and Nikolas Stürchler, The Threat of Force in International Law (Cambridge: Cambridge University Press, 2007).

44 In its advisory opinion on the 
'Legality of the Threat or Use of Nuclear Weapons', the International Court of Justice held that it was unlawful to issue threats that would be illegal if carried out in practice, and suggested that the use of nuclear weapons would generally be contrary to international humanitarian law. The court declined to pass judge-ment on whether the use of nuclear weapons would be unlawful when the 'survival' of the state using nuclear weapons was in jeopardy. This could be interpreted to sug-gest that the threat or use of nuclear weapons would not be permissible if carried out on behalf of another state, as the survival of the user would presumably not be in jeopardy. See Nobuo Hayashi, 'Legality Under Jus ad Bellum of the Threat of Use of Nuclear Weapons', in Gro Nystuen, Stuart Casey-Maslen and Annie G. Bersagel (eds), Nuclear Weapons Under International Law (Cambridge: Cambridge University Press, 2014).
45 Stuart Casey-Maslen, The Treaty on the Prohibition of Nuclear Weapons: $A$ Commentary (Oxford: Oxford University Press, 2019), para. 1.81.

See, for example, Michael J. Mazarr, 'Virtual Nuclear Arsenals', Survival, vol. 37, no. 3, Autumn 1995, pp. 7-26.

47 Quinlan, Thinking About Nuclear Weapons, p. 161.

48 See Campbell Craig, 'Solving the

Nuclear Dilemma: Is a World State Necessary?', Journal of International Political Theory, 9 September 2018, https://doi. org/10.1177/1755088218795981.

49 See Walter Krutzsch, 'Article 1: General Obligations', in Walter
Krutzsch, Eric Myjer and Ralf Trapp (eds), A Commentary on the Chemical Weapons Convention (Oxford: Oxford University Press, 2014), p. 67.

50 NATO, Active Engagement, Modern Defence: Strategic Concept for the Defence and Security of the Members of the North Atlantic Treaty Organization', November 2010, para. 19.

51 See Theresa May, 'UK's Nuclear Deterrent', House of Commons Hansard, 18 July 2016, http://hansard. parliament.uk/ Commons/2016-07-18/debates/7B7A196BB37C-4787-99DC-098882B3EFA2/ UKSNuclearDeterrent; and Tom Batchelor, 'Defence Secretary Says World More "Dangerous \& Unpredictable" Now than During the Cold War', Express, 22 January 2016, http:// www.express.co.uk/news/uk/637003/ Trident-weapons-Michael-Fallon-UKnuclear-submarines-dangerous-world.

52 William Perry et al., America's Strategic Posture: The Final Report of the Congressional Commission on the Strategic Posture of the United States (Washington DC: United States Institute for Peace Press, 2009), p. 8.

53 See Ine Eriksen Søreide, remarks in the Norwegian parliament (Stortinget), 14 November 2018, https:// www.stortinget.no/no/Saker-ogpublikasjoner/Publikasjoner/Referater/ Stortinget/2018-2019/ refs-201819-11-14?m=1.

54 Casey-Maslen, The Treaty on the Prohibition of Nuclear Weapons, paras 1.88-1.118. See also International Human Rights Clinic, 'Nuclear Umbrella Arrangements and the Treaty on the Prohibition of Nuclear Weapons'.

55 This point was raised during the 
debate about a potential Nordic nuclearweapon-free zone in the 1980s. See Johan J. Holst, 'The Pattern of Nordic Security', Dædalus, vol. 113, no. 2, 1984, p. 217.

56 US Strategic Command, 'Essentials of Post-Cold War Deterrence', 1995,

p. 7, http://www.nukestrat.com/us/ stratcom/SAGessentials.PDF.

57 Schelling, Arms and Influence, p. 52.

58 See, for example, Michael Krepon,

'The Folly of Tactical Nuclear Weapons', Defense One, 2 October 2017, https:// www.defenseone. com/technology/2017/10/ folly-tactical-nuclear-weapons/141440/.

59 See Cheryl Rofer, 'On the Lack of Analytical Utility of the Concept of Deterrence', Nuclear Diner, 19 February 2019, https://nucleardiner. wordpress.com/2019/02/19/ on-the-lack-of-analytical-utility-of-theconcept-of-deterrence/.

60 See, for example, Simon J. Moody, 'Enhancing Political Cohesion in NATO During the 1950s or: How It Learned to Stop Worrying and Love the (Tactical) Bomb', Journal of Strategic Studies, vol. 40, no. 6, 2017, p. 828; and Tannenwald, The Nuclear Taboo, pp. 143, 169-70.

61 Rühle, 'The Nuclear Weapons Ban Treaty'.
62 See T.V. Paul, 'Nuclear Taboo and War Initiation in Regional Conflicts', Journal of Conflict Resolution, vol. 39, no. 4, 1995, pp. 696-717.

63 See Rebecca Johnson, Unfinished Business: The Negotiation of the CTBT and the End of Nuclear Testing (Geneva: UNIDIR, 2009), pp. 11-15.

64 See David Mutimer, 'From Arms Control to Denuclearization', Contemporary Security Policy, vol. 32, no. 1, 2011, pp. 57-75; and Keith Krause, 'Leashing the Dogs of War', Contemporary Security Policy, vol. 32, no. 1, 2011, pp. 20-39.

65 See, for example, Alan Robock and Owen B. Toon, 'Self-assured Destruction: The Climate Impacts of Nuclear War', Bulletin of the Atomic Scientists, vol. 68, no. 5, 2012, pp. 66-74.

66 Craig distinguishes between 'reformist' and 'radical' approaches to nuclear security, placing normative efforts such as the humanitarian initiative and negotiation of the TPNW in the former bracket. It could be argued, however, that delegitimising nuclear weapons would be a necessary condi-tion for the implementation of certain 'radical' proposals, such as the aboli-tion of nuclear weapons by a world government. See Craig, 'Solving the Nuclear Dilemma'. 